\title{
An investigation on the properties of polyester textured yarns produced with different fiber cross-sectional shapes
}

\section{REZUMAT - ABSTRACT}

\section{Studiu asupra proprietăților firelor texturate de poliester cu diverse forme de secțiune transversală a fibrei}

În acest studiu, s-au examinat efectele diferitelor forme de secțiune transversală a fibrei și ale valorilor densității liniare asupra caracteristicilor firelor parțial orientate (POY) și firelor texturate. În cadrul experimentului, au fost utilizate cinci forme diferite de secțiune transversală, și anume: rotunde, trilobale, tetralobale, hexalobale și octolobale, și două densități liniare diferite și au fost aplicate testele de tenacitate-alungire, ondulare și contracție a firelor. Ca rezultat, formele de secțiune transversală rotunde și octolobale au condus la formarea firelor cu tenacitate și alungire la rupere ridicată, iar pe de altă parte cele cu forme trilobale și hexalobale au determinat o tenacitate și alungire la rupere scăzută. Secțiunea transversală rotundă a condus la formarea firelor cu grad ridicat de ondulare și contracție scăzută, iar formele hexalobale și tetralobale ale secțiunii transversale au determinat o ondulare mai scăzută și o contracție ridicată. De asemenea, s-a observat că o creșterea a densității liniare determină o scădere a tenacității firelor, care conduce la un comportament de ondulare și o contracție ridicată a firelor.

Cuvinte-cheie: polyester POY, fir texturat, secțiune transversală a fibrei, proprietățile firului

\section{An investigation on the properties of polyester textured yarns produced with different fiber cross-sectional shapes}

In this study, the effects of different fiber cross-sectional shapes and yarn linear density values on Partially Oriented Yarn (POY) and textured yarn characteristics have been examined. In experiment, five different cross-sectional shapes, namely round, trilobal, tetra, hexsa and octolobal and two different linear densities have been used and tenacityelongation, crimp and shrinkage tests have been applied to the yarns. As a result, the round and octolobal crosssectional shapes lead to yarn formation with high tenacity and breaking elongation, on the other hand trilobal and hexsa cause low tenacity and breaking elongation. The round cross-section has provided yarn formation with high crimp and low shrinkage, the hexsa and tetra cross-sectional shapes have caused lower crimp and high shrinkage. It was also observed that the increase in the linear density has caused a decrease in yarn tenacity, however this has increased the crimp and shrinkage behaviours of the yarns.

Keywords: polyester POY, textured yarn, fiber cross-section, yarn properties

\section{INTRODUCTION}

Filament yarns can be produced with the melt spinning process and these yarns have flat and unbulked structure, low tenacity and highly breaking elongation, high-luster properties, etc. Generally, these properties are developed with texturizing process. Besides, there are various structural parameters (number of filament, cross-sectional shape, linear density, etc.) determined during the production of filament yarns and these parameters influence these product features. Among these parameters, crosssectional shape of fibers has a significant importance.

Currently, it is known that a change in fiber cross-sectional shape has an important effect on the features of fabric such as feel, mechanical feature, comfort, etc. Several studies were carried out on the effect of fiber cross-sectional shapes on yarn and fabric properties [1-4]. For instance, Varshney et. al. have carried out detailed studies on this subject in 2010 and $2011[5,6]$.

The texturing process is applied on flat, non-bulk synthetic filament yarns with a rather brighter structure.
With this process, it is also aimed to have the natural appearance and the feel of yarn which are obtained from natural fibers. Moreover, filament yarn properties such as higher cover factor, higher thermal insulation, higher water vapour permeability and higher tenacity and lower breaking elongation can also be obtained with the texturing process. Thus, a big majority of filament yarns are used after texturing process. False twist and air jet texturing processes are the most frequently used methods among various techniques. Also, when different texturing techniques are applied on the same filament yarn groups, these textured yarn properties can be different from each other. Moreover, with changing production parameters of the same texturing technique, the filament yarn properties are also changing. Thus, texturing process is complicated and contains many production parameters. When the previous studies on textured yarn are examined, it is seen that these studies mostly focus on the changing of textured yarn production parameters (temperature, $\mathrm{D} / \mathrm{Y}$ ratio, etc.) and the effects of these parameters on yarn properties [7-12]. Besides, the studies examining the effect 


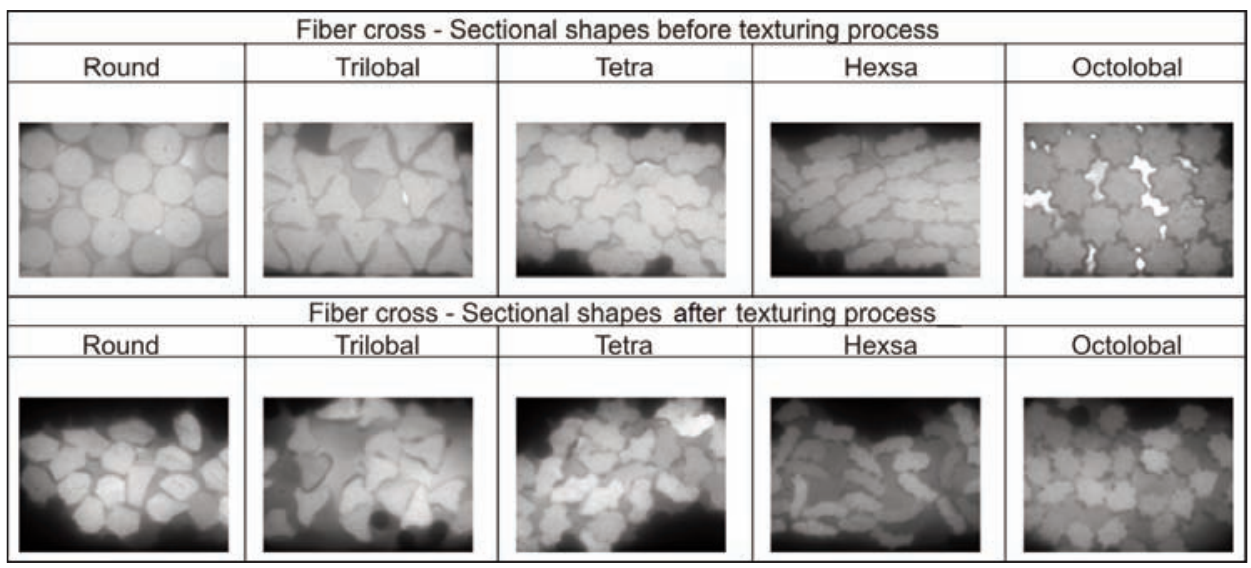

Fig. 1. Fiber cross-sectional shapes used in the study (X500 magnification) [14]

of different yarn structural parameters on product properties are rather oriented towards staple fiber and/or knitted/woven fabric performances [1-5, 13]. This paper examined the effect of different fiber cross-sectional shapes on the properties of flat and textured yarns.

\section{EXPERIMENTAL WORK}

\section{Materials and method}

Polyester (PES) flat and textured yarns, which have an important place and an extensive area of use among synthetic yarns, have been used as materials in this study. Also, two different yarn groups have been used in the study with 34 and 47 filaments because there were spinneret of 34 filaments for tetra cross-sectional shapes and 47 filaments for hexsa cross-sectional shapes under the process condition of the study. Hence, cross sectional shapes have been grouped according to their number of filaments. The first yarn group has round, trilobal, tetra and octolobal cross-sectional shapes while the second yarn group has round, hexsa and octolobal crosssectional shapes. The images of fiber cross-sectional shapes before and after the texturing process have been provided in figure 1 .

It is seen in the pictures that the distinct cross-sectional shapes of the individual filaments constituting the yarn at the beginning have partially been deformed after the texturizing process. PES flat yarns have been produced according to melt spinning principle. Production parameters of these yarns have been provided in table 1 .

False twist texturing technique was used and 1.6 drawing ratio applied on the flat yarns with the texturizing process. During the flat and textured yarns production process, all other parameters except for the factors whose effects were aimed to be investigated were kept constant. False-twist texturing process and production parameters of textured yarns are given in figure 2 and table 2 respectively.

The shape of the filament cross-section slightly changes the level of heat transfer during the contact

\begin{tabular}{|l|l|c|}
\hline \multicolumn{2}{|c|}{ PRODUCTION PARAMETERS OF PES } \\
FLAT YARN [15]
\end{tabular}

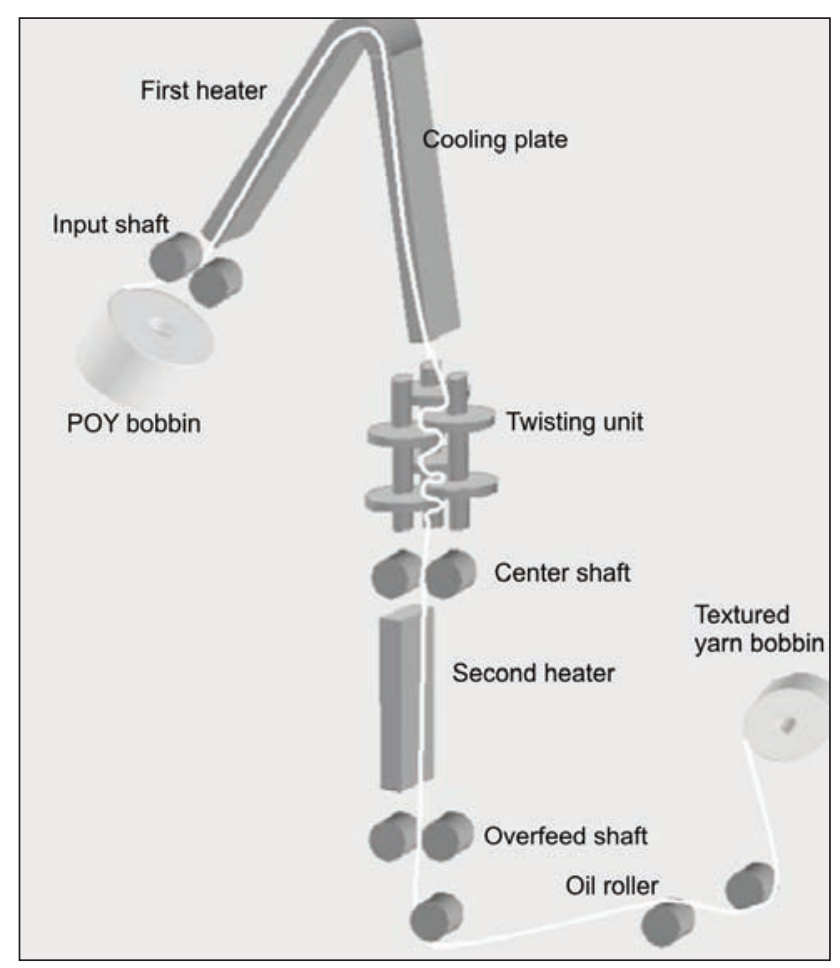

Fig. 2. False-twist texturing process [13] 


\begin{tabular}{|l|c|}
\hline \multicolumn{2}{|l|}{ PRODUCTION PARAMETERS OF TEXTURED YARNS } \\
\hline Feed Roller Speed (m/min.) & 364 \\
\hline Delivery Roller Speed (m/min.) & 600 \\
\hline Take-up Roller Speed (m/min.) & 573 \\
\hline Winding Roller Speed (m/min.) & 576 \\
\hline Disc Speed (m/min.) & 1711 \\
\hline Yarn Speed $(\mathrm{m} / \mathrm{min})$. & 900 \\
\hline D/Y Ratio & 1,90 \\
\hline First Heater Temp. $\left({ }^{\circ} \mathrm{C}\right)$ & 180 \\
\hline Second Heater Temp. $\left({ }^{\circ} \mathrm{C}\right)$ & 130 \\
\hline Disc Fineness $(\mathrm{mm})$ & 6 \\
\hline Disc Material & Ceramic \\
\hline Lubricant & Polyurethane \\
\hline Winding Angle $\left({ }^{\circ}\right)$ & Spreiton 1384 \\
\hline Conical Angle $\left({ }^{\circ}\right)$ & 27 \\
\hline
\end{tabular}

The tenacity and breaking elongation tests repeated thirty times for each yarn and the average values were obtained. Eighteen tests for each yarn sample were performed during experimental studies of crimp and shrinkage tests. While tenacity and breaking elongation tests were applied to flat yarns at $200 \mathrm{~mm}$ length and textured yarns at $500 \mathrm{~mm}$, crimp and shrinkage tests were applied to hank of textured yarns. Information of these test conditions have been given in table 3.

The effects of cross-sectional shape factor on the characteristics of textured yarns were statistically analyzed by using the general linear model-univariety method. The statistical study was carried out at a reliability level of $\alpha=0,05$.

\section{RESULTS AND DISCUSSION}

\section{Yarn tenacity and breaking elongation}

Tenacity and breaking elongation tests applied on the yarns which have 34 filaments and round, trilobal, tetra and octolobal cross-sectional shaped that constituted the first group of the study have been provided in figures 3 and 4 . When the graphics are examined, one of the remarkable results is that after the texturizing process, the tenacity values increased but the breaking elongation values decreased. The high tenacity of the textured yarn compared to flat yarn can be explained that the texturizing process with drawing increased the orientation factor in the filament structure and that ultimately the textured yarn tenacity increased. Because of drawing on texturizing process for the yarns resulted that textured yarns have lower breaking elongation compared to the flat yarns. It can also be seen that the tenacity and breaking elongation of flat and textured yarns with trilobal cross-sectional structure are lower than those with other cross-sectional shapes, and that the highest values lie with the round cross-sectionally shaped yarns.

It can be also seen that the flat yarns with 283 and 133 dtex linear densities are lowered 178 and 84 dtex linear densities respectively because of drawing at a certain amount during texturizing process. With the

\begin{tabular}{|c|c|c|c|c|c|c|c|c|c|c|c|}
\hline \multicolumn{12}{|c|}{ INFORMATION OF TEST CONDITIONS OF FLAT AND TEXTURED YARNS $[17,18]$} \\
\hline Test name & \multicolumn{2}{|c|}{$\begin{array}{l}\text { Test speed } \\
(\mathrm{mm} / \mathrm{min} .)\end{array}$} & Principle & \multicolumn{2}{|c|}{$\begin{array}{c}\text { Clamp } \\
\text { pressure-Pcl } \\
\left(\mathrm{N} / \mathrm{cm}^{2}\right)\end{array}$} & \multicolumn{2}{|c|}{$\begin{array}{l}\text { Hank length } \\
\qquad(\mathrm{cm})\end{array}$} & \multicolumn{3}{|c|}{$\begin{array}{l}\text { Pretension } \\
\text { (cN/tex) }\end{array}$} & Time \\
\hline \multirow{2}{*}{$\begin{array}{l}\text { Tenacity and breaking } \\
\text { elongation }\end{array}$} & POY & Tex. & \multirow{2}{*}{ CRE } & POY & Tex. & \multirow{2}{*}{\multicolumn{2}{|c|}{ - }} & & & Tex. & \multirow{2}{*}{ * } \\
\hline & 750 & 380 & & 225 & 338 & & & \multicolumn{2}{|c|}{8,9} & 27,6 & \\
\hline \multirow{2}{*}{ Crimp } & \multirow{2}{*}{\multicolumn{2}{|c|}{$\begin{array}{c}5000 \\
\text { (loading } \\
\text { speed) } \\
\end{array}$}} & \multirow{2}{*}{ - } & \multirow{2}{*}{\multicolumn{2}{|c|}{ - }} & 84 dtex & 178 dtex & $\mathrm{L}_{\mathrm{g}}$ & $L_{f}$ & $\mathrm{~L}_{\mathrm{b}}$ & \multirow{2}{*}{$\begin{array}{c}10 \text { min. } \\
\text { (recovering } \\
\text { period) }\end{array}$} \\
\hline & & & & & & 1400 & 700 & 2 & 0.1 & 10 & \\
\hline \multirow{2}{*}{ Shrinkage } & \multirow{2}{*}{\multicolumn{2}{|c|}{$\begin{array}{l}150 \\
\text { (loading } \\
\text { speed) }\end{array}$}} & \multirow{2}{*}{ - } & \multirow{2}{*}{\multicolumn{2}{|c|}{ - }} & $84 \mathrm{dtex}$ & 178 dtex & \multirow{2}{*}{\multicolumn{3}{|c|}{2.0}} & \multirow{2}{*}{$\begin{array}{l}10 \mathrm{sec} . \\
\text { (loading } \\
\text { period) }\end{array}$} \\
\hline & & & & & & 2800 & 6000 & & & & \\
\hline
\end{tabular}

* Time has changed depending on breaking time of yarns 


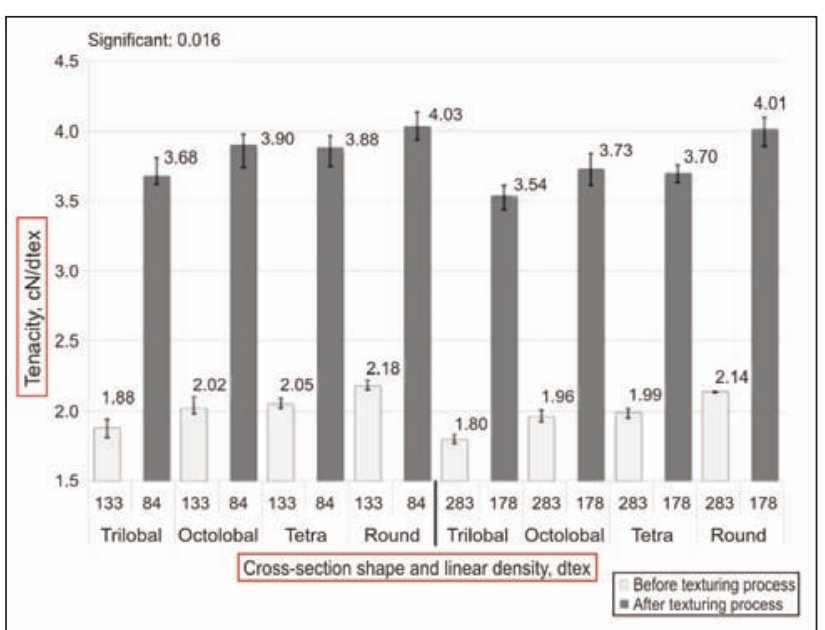

Fig. 3. Effect of fiber cross-sectional shape and yarn linear density on yarn's tenacity-34 filaments

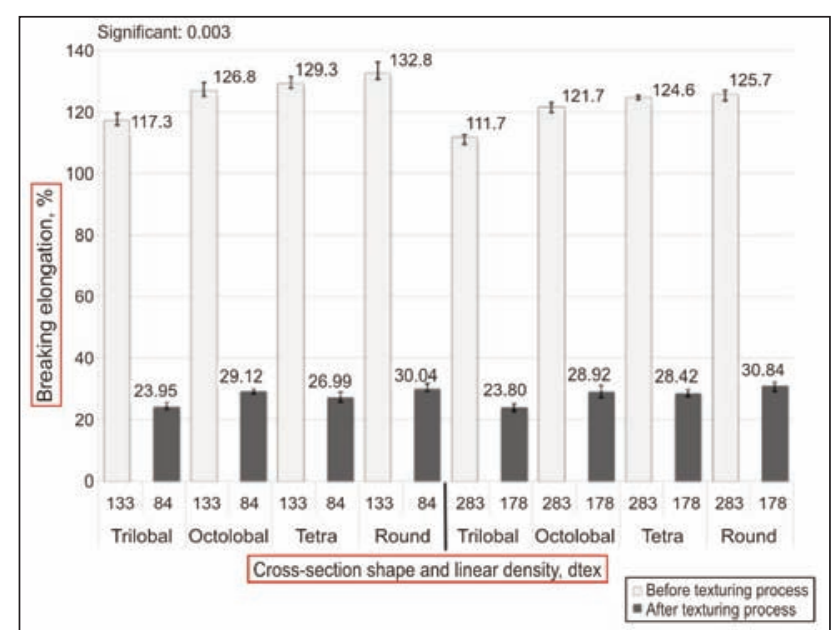

Fig. 4. Effect of fiber cross-sectional shape and yarn linear density on yarn's breaking elongation-34 filaments drawing effect on the yarns the tenacity values of these yarns are increased. As the significance level of the tenacity results was found as 0,016 and that of the breaking elongation results was found as 0,003 at a reliability level of $\alpha=0,05$, meaning that the effect of cross-sectional shape variable on the tenacity and breaking elongation of textured yarns are statistically significant.

The second group of the study is composed of 47 filaments with round, hexsa and octolobal cross-sectional shaped of flat and textured yarns. The effect of the cross-sectional shape and linear density values of these yarns on tenacity and breaking elongation have been examined and the results have been interpreted in figures 5 and 6 . It is observed that after the texturizing process the tenacity values of the yarns increased and the breaking elongation values decreased. In addition to this for flat and textured yarns, the yarns produced with hexsa cross-sectional shape had the lowest tenacity and breaking elongation compared to other cross-sectional shapes. This result can be explained that the adherence features because of hexsa cross-section compared with

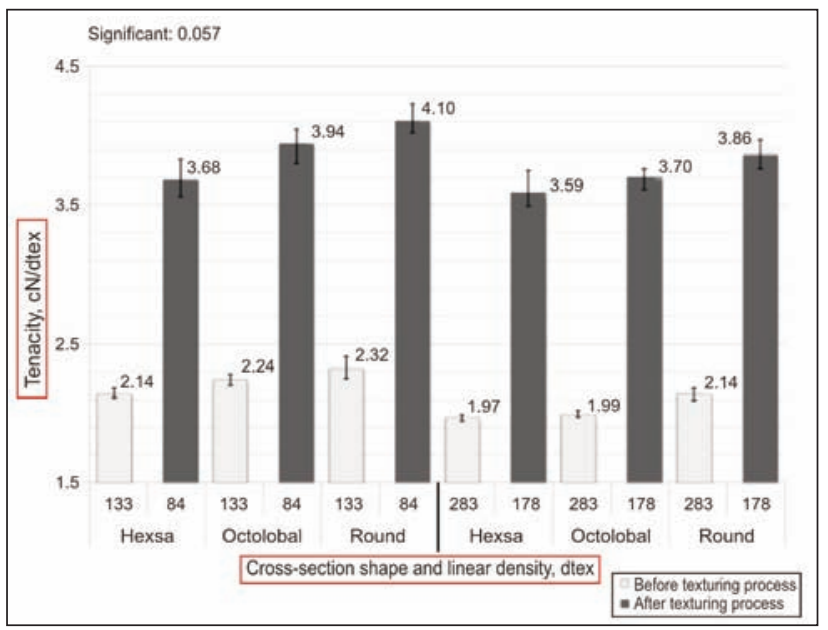

Fig. 5. Effect of fiber cross-sectional shape and yarn linear density on yarn's tenacity- 47 filaments the other cross-sectional shaped yarns. Examining previous studies like this topic in the literature we can see that round cross-sectional shape shows ideal mechanical properties according to lobed and channeled cross-sectional shapes [14-15, 19].

According to the statistical analysis, the significance level of the tenacity results was found as 0,057 and that of the breaking elongation results was found as 0,043 at a reliability level of $\alpha=0,05$. Although there is a difference in the tenacity test results of textured yarns, the finding was not significant statistically but breaking elongation results found to be significant.

\section{Textured yarn crimp and shrinkage properties}

"Crimp Contraction" property is essentially assessed on false-twist textured yarns and is defined as the contraction of a textured yarn due to crimp development, expressed as percentage rate (CC\%) on the stretched out (uncrimped) yarn length [20]. When the CC\% values of the yarns consisting of both groups the highest crimp value was on round cross-section and the lowest crimp value was on tetra and hexsa cross-sectional shapes (figures 7,8 ). This result can

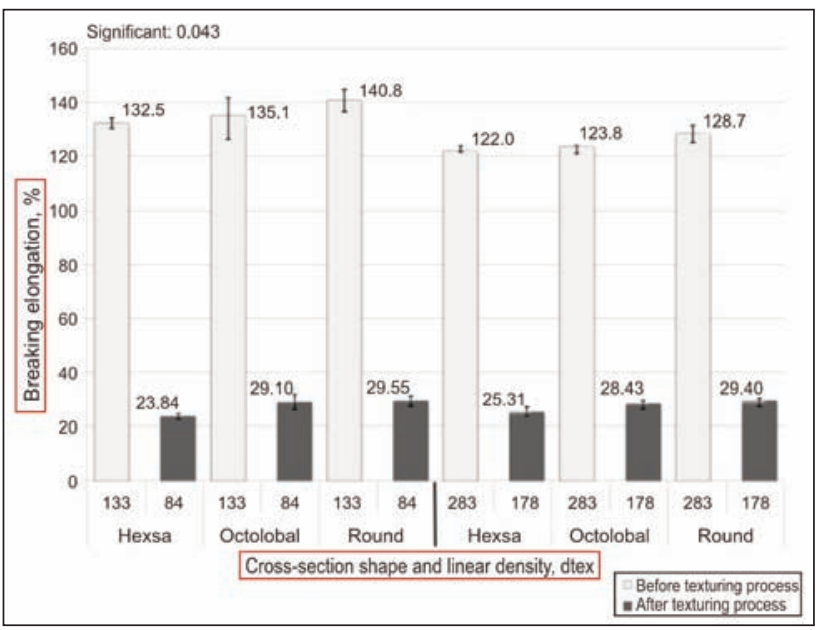

Fig. 6. Effect of fiber cross-sectional shape and yarn linear density on yarn's breaking elongation-47 filaments 


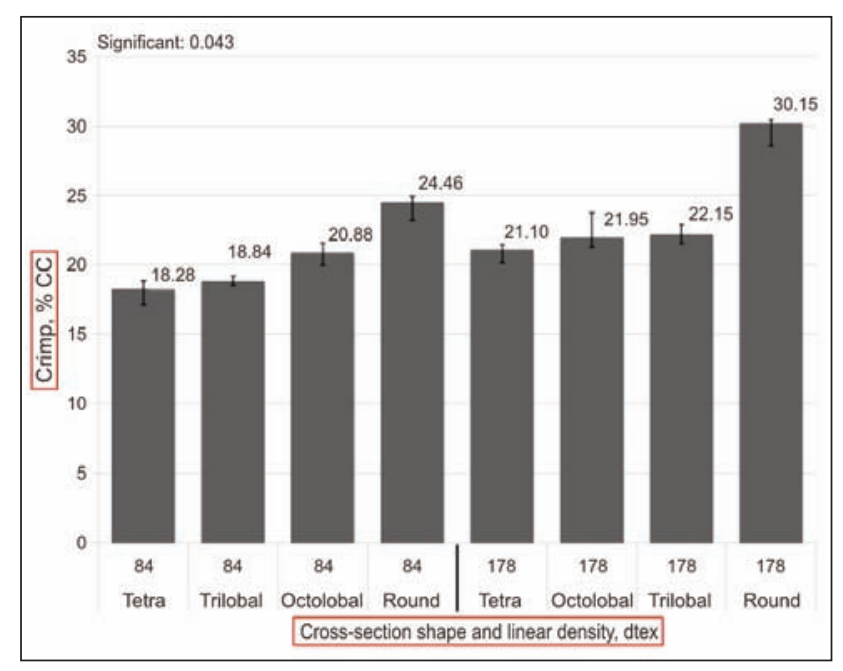

Fig. 7. Effect of fiber cross-sectional shape and yarn linear density on yarn's crimp-34 filaments

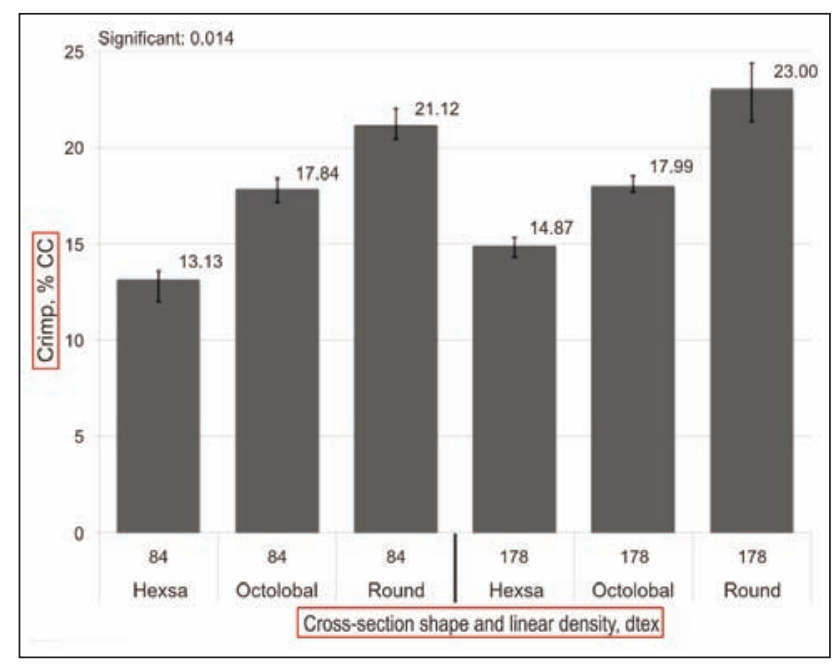

Fig. 8. Effect of fiber cross-sectional shape and yarn linear density on yarn's crimp-47 filaments [21] be explained that round cross-sectional shaped filaments with a more bulky structure combine and provide formation of more bulked yarns. On the other hand, because of channelled structures of tetra and hexsa cross-sectional shapes, they were deformed more easily while texturing and as a result they caused more flat, thin and unbulked filaments (figure 1). In addition to the increase in linear density provided that the yarns had a more bulky structure as expected. As also seen in figure 7 and figure 8, the first group of yarns with 34 filaments possesses higher \%CC values than second group of yarns with 47 filaments. It was also found that the significance level of the crimp test results of the first group yarns with reliability level $\alpha=0,05$ was 0,043 and that of the second group yarns was 0,014 . Thus, the impact of the cross-sectional shape variable on the textured yarn was statistically significant in both groups. Consequently, structural parameters of filament yarns (cross-sectional shape, linear density, number of filament, etc.) have affected crimp properties of textured yarns.

Shrinkage in fibers, yarns and fabrics can be determined by a great number of different methods in which the changes in length after contraction are measured under defined conditions [22]. In this study, hot-air shrinkage test has been applied on textured filament yarns according to DIN 53840-2; 1983 test standard with Texturmat-ME test device. Figures 9 and 10 display the effects of cross-section and linear density on the shrinkage of textured yarns with 34 and 47 filaments in yarn cross-section. It is observed that the textured yarns have different shrinkage peculiarities according to their cross-section and linear density. Textured yarns with 34 filaments and with 84 dtex linear density the highest shrinkage was in the tetra cross-sectional shape and the lowest shrinkage was in the round and octolobal cross-sectional shapes. Among the yarns with 178 dtex linear density the highest shrinkage value was in the round and the lowest shrinkage value was in the octolobal

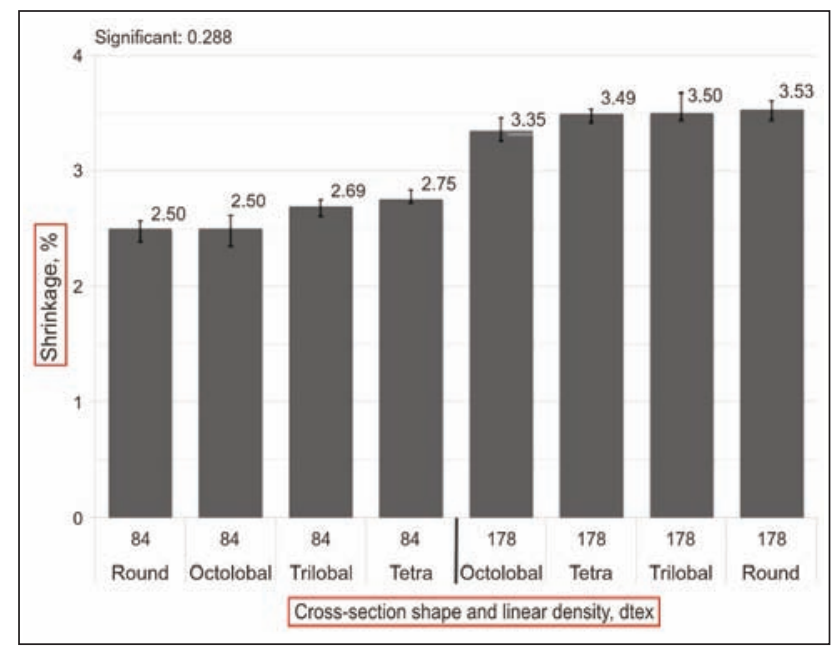

Fig. 9. Effect of fiber cross-sectional shape and yarn linear density on yarn's shrinkage-34 filaments

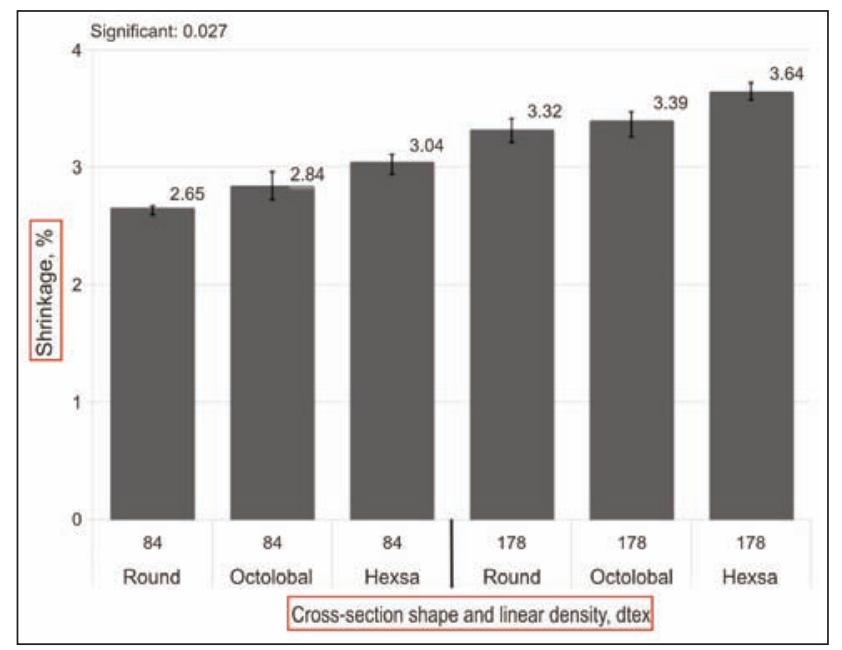

Fig. 10. Effect of fiber cross-sectional shape and yarn linear density on yarn's shrinkage-47 filaments [21] 
cross-sectional shapes (figure 9). As a result, the shrinkage values when compared with cross-sectional shapes display neither a certain increase nor a decline.

The shrinkage test results of the second group textured yarns with 47 filaments have been shown in figure 10. As seen in figure, the highest shrinkage value is at the hexsa cross-sectional shaped yarns and the lowest shrinkage value is at the round cross-sectionally shaped yarns. Textured yarns produced with round cross-sectional shapes possess more resistance to temperature compared to hexsa and octolobal cross-sectional shapes. This result can be explained that due to the good cohesion and bulky structure of the round cross-sectional shape filaments and they display a more resistance towards the heat. Because of deep channel cross-sectional shape of hexsa textured yarns, more heat has penetrated to their structure. According to the statistical analysis results, the significance value of the shrinkage tests of the first group yarns with reliability level $\alpha=0,05$ was found to be 0,288 and that of the second group yarns was 0,027 . It has been understood that the effect of the cross-sectional shape on the shrinkage of the first group textured yarns was not statistically significant but that its impact on the second group yarns was statistically significant.

\section{CONCLUSIONS}

In the study, the effects of selected cross-sectional shapes and two different linear density values on PES flat and textured yarn features have been examined. Consequently, there was a tendency for increase in the tenacity values of the yarns and for decrease in the breaking elongation values after the texturizing process. Furthermore, round cross-sectional shaped yarn has resulted positive effects on high tenacity, high breaking elongation, high crimp value and low shrinkage on textured yarn. The first yarn group of this study, the tenacity and breaking elongation values of trilobal cross-sectional shape are lower than those with other cross-sectional shapes (round, tetra and octolobal) and that the highest values lie with the round cross-sectionally shaped yarns in the same group. In the second group of this study, the yarns produced with hexsa cross-sectional shape had lower tenacity and breaking elongation values compared to other cross-sectional shapes. Yarns with channeled and lobed cross-sectional shape gave the results of lower tenacity and breaking elongation values. It was also observed that the increase in the linear density value decreased the tenacity and breaking elongation values of the yarns. When the CC\% values of the yarns consisting of both groups of the study are examined, the highest crimp value was in the round cross-section and the lowest crimp value was in the tetra and hexsa cross-sectional shapes. The shrinkage values of yarns when compared with cross-sectional shapes display neither a certain increase nor a decline. Also, the increase in linear density value increased the shrinkage values as expected.

\section{ACKNOWLEDGEMENTS}

We extend our thanks to SASA Polyester San. A.Ş. Management and employees of related departments, who provided all the necessary opportunities for the carrying out of the tests and the production of the basic materials of this study, which was conducted with the cooperation of Çukurova University and SASA Polyester San. A.Ş. within the scope of "Academic Support Project".

\section{BIBLIOGRAPHY}

[1] Matsudaira, M., Tan, Y., Kondo, Y. The Effect of fibre cross-sectional shape on fabric mechanical properties and handle, In: The Journal of the Textile Institute, 1993, vol. 84, no 3, pp. 376-386

[2] Bozdoğan, F. Effect of fiber cross-sectional shape on aesthetic properties of textile product, In: Textile\&Technical, 2000, 184, pp. 136-140

[3] Bueno, M., Aneja, A.P., Renner, M. Influence of the shape of fiber cross-section on fabric surface characteristics, In: Journal of Materials Science, 2004, 39, pp. 557-564

[4] Tascan, M., Vaughn, E. Effects of fiber denier, fiber cross-sectional shape and fabric density on acoustical behavior of vertically lapped nonwoven fabrics, In: Journal of Engineered Fibers and Fabrics, 2008, 3, pp. 32-38.

[5] Varshney, RK., Kothari, VK., Dhamija, S. A study on thermophysiological comfort properties of fabrics in relation to constituent fibre fineness and cross-sectional shapes, In: The Journal of the Textile Institute, 2010, vol. 101, no. 6, pp. 495-505

[6] Varshney, RK., Kothari, V.K., Dhamija, S. Influence of polyester fibre fineness and cross-sectional shape on lowstress characteristics of fabrics, In: The Journal of the Textile Institute, 2011, vol. 102, no. 1, pp. 31-40

[7] Karakaş, C., Dayıoğlu, H. Influence of major false-twist texturing parameters on the structural properties of polyamide 6.6 yarn, In: Fibers\&Textiles in Eastern Europe, 2004, 12, pp. 23-28

[8] Vitkauskas, A., Miglinaite, R., Vesa, P., Puolakka, A. Mechanical properties of polypropylene multifilament yarns in dependence of their drawing ratio, In: Materials Science, 2004, vol. 11, no. 4, pp. 407-410

[9] Çirkin, S. Effect of texturing variables on the yarn properties during false-twist texturing process, In: MSc Thesis, 2006, University of Çukurova, Turkey 
[10] Yıldırım, K., Altun, Ş., Ulcay, Y. The effect of first heater temperature on the properties of false-twist textured poly (ethylene terapthalate) yarn, In: Journal of Textile and Apparel, 2009, vol. 19, no. 4, pp. 286-290

[11] Koç, S., Hockenberger, A. Investigation of air-jet texturing of technical polyester yarns, In: Journal of Textile and Apparel, 2010, vol. 20, no. 4, pp. 299-305

[12] Tehran, M., Azimi, B., Mojtahedi, M. Investigating the effect of false twist texturing process on the color coordinates variation of spun-dyed polyester filament yarns, In: Journal of Engineered Fibers and Fabrics, 2011, 6(4), pp. 54-62

[13] Yıldırım, K., Altun, Ş., Ulcay, Y. Relationship between yarn properties and process parameters in false-twist textured yarn, In: Journal of Engineered Fibers and Fabrics, 2009, vol. 4, no. 2, pp. 26-32

[14] Özkan, S. Effect of filament cross-section shape, number of filaments and filament linear density on the properties of POY and textured yarn, MSc Thesis, 2008, University of Çukurova, Turkey

[15] Babaarslan, O., Hacıoğulları, SO. Effect of fibre cross-sectional shape on the properties of POY continuous filament yarns, In: Fibers and Polymers, 2013, vol. 14, no. 1, pp. 146-151

[16] Hes, L., Ursiny, P. Yarn Texturing Technology, In: Comett Eurotex, EUROTEX Head Office: Universidade do Minho, 1994, p. 149

[17] BS EN ISO 2062: Textile-Yarns From Packages: Determination of single-end breaking force and elongation at break, 1995

[18] DIN 53840-2: Testing of Textiles: Determination of parameters for the crimp of textured filament yarns, 1983

[19] Karaca, E., Özçelik, F. Influence of the cross-sectional shape on the structure and properties of polyester fibers, In: Journal of Applied Polymer Science, 2007, 10, pp. 2615-2621

[20] Andreoli, C., Freti, F. Textile Process, In: Man-Made Fibres, Edited by Fondazione Azimit, Milano-Italy, 2006, pp. 35-36

[21] Babaarslan, O., Hacıoğulları, SO. Properties of POY and textured yarn with different cross-sectional shapes, In: The Fiber Society Spring 2012 Conference-Fibers Research for Tomorrow's Applications, Empa, St. Gallen, Switzerland, 2012, pp. 87-88

[22] Militky, J., Kremanakova, D., Kosatkova-Huskova, M. Shrinkage rate of polyester for membrane applications, 2010, In: 7th International ConferenceTEXSCI-2010

\section{Authors:}

\section{SELCEN ÖZKAN HACIOĞULLARI OSMAN BABAARSLAN}

Çukurova University

Faculty of Engineering and Architecture, Department of Textile Engineering Saricam-01330, Adana-TURKEY

e-mail: selcenozkan@gmail.com, teksob@cu.edu.tr

Corresponding author:

\section{SELCEN ÖZKAN HACIOĞULLARI}

e-mail: selcenozkan@gmail.com 